\title{
Profil dan Kompetensi Guru Bahasa Arab Madrasah Aliyah Negeri di Bangka Belitung
}

\author{
Syarifah $^{1}$, Iskandi $^{2}$ \\ Fakultas Tarbiyah \\ IAIN Syaikh Abdurrahman Siddik Bangka Belitung, Indonesia \\ ${ }^{1}$ syarifahjunaidi@gmail.com, ${ }^{2}$ iskandi7man@yahoo.co.id
}

\begin{abstract}
This article aims to describe the profile of Madrasah Aliyah Negeri Arabic language teachers in the Bangka Belitung Islands Province, the relevance of the academic qualifications of Arabic language teachers with subjects taught in Madrasah Aliyah Negeri, and the competence of Arabic language teachers in terms of students' perspectives. The research method used is descriptive quantitative, with data collection techniques such as questionnaires and documentation. The results showed that when viewed from academic qualifications, Arabic teachers who already have PBA S1 academic qualifications had a percentage of $80 \%$ and other S1 academic qualifications of $20 \%$. Referring to these data, the relevance of Arabic language science to subjects taught based on academic qualifications is 80:20. Whereas if the scientific relevance is reviewed from the professional certificate, Arabic teachers who have professional certificates as professional Arabic teachers are 60\% and those that have not been certified are 40\%. Based on students' perspectives, the competence of Arabic language teachers in Madrasah Aliyah Negeri Bangka Belitung Islands Province is as follows: Pedagogical Competence with a mean score of 2.64, Professional Competence of 3.00, Social Competence of 3.03, and Personality Competence of 3.04. The overall average score of the four competencies is 2.99 with the interpretation "Enough". Of the three madrasas that are the objects of research, teachers pedagogical competence is a major issue that needs teachers attention.
\end{abstract}

Tujuan dari penelitian ini adalah untuk mendeskripsikan profil guru bahasa Arab Madrasah Aliyah Negeri di Provinsi Kepulauan Bangka Belitung, relevansi kualifikasi akademik guru bahasa Arab dengan mata pelajaran yang diampu di Madrasah Aliyah Negeri, serta kompetensi guru bahasa Arab ditinjau dari perspektif siswa. Penelitian ini menggunakan pendekatan deskriptif kuantitatif dengan teknik pengumpulan data berupa angket dan dokumentasi. Hasil penelitian menunjukkan bahwa jika ditinjau dari kualifikasi akademik, guru bahasa Arab yang sudah memiliki kualifikasi akademik S1 PBA memiliki prosentase sebesar 80\% dan kualifikasi akademik S1 lainnya sebesar 20\%. Mengacu kepada data tersebut relevansi keilmuan guru bahasa Arab dengan mata pelajaran yang diampu berdasarkan kualifikasi akademik sebesar 80:20. 
|SYARIFAH | Profil dan Kompetensi Guru Bahasa Arab...

Sedangkan jika relevansi keilmuan ditinjau dari sertifikat pendidik, guru bahasa Arab yang memiliki sertifikat pendidik sebagai guru bahasa Arab profesional sebesar $60 \%$ dan yang belum tersertifikasi sebesar 40\%. Berdasarkan perspektif siswa kompetensi guru bahasa Arab di Madrasah Aliyah Negeri Provinsi Kepulauan Bangka Belitung adalah sebagai berikut: rerata skor kompetensi pedagogik sebesar 2.64, rerata skor kompetensi profesional sebesar 3.00, kompetensi sosial memiliki rerata skor sebesar 3.03, dan rerata skor untuk kompetensi kepribadian sebesar 3.04. Rerata skor secara umum dari empat kompetensi tersebut adalah 2.99 dengan interpretasi "Cukup". Dari ketiga madrasah yang menjadi obyek penelitian, kompetensi pedagogik guru menjadi persoalan utama yang perlu mendapat perhatian guru.

Keywords: Profile, Competencies, Arabic Language Teachers

\section{A. Pendahuluan}

Pendidikan merupakan hak setiap warga negara. ${ }^{1}$ Pendidikan memiliki peranan yang sangat menentukan bagi keberlangsungan suatu bangsa. Cara pandang suatu bangsa dalam mengenali, menghargai dan memanfaatkan sumber daya manusia sangat berpengaruh terhadap kemajuan bangsa tersebut dan juga terkait erat dengan kualitas pendidikan yang diterima oleh peserta didik dalam masyarakat. Dalam Undang-undang Republik Indonesia Nomor 20 Tahun 2003 tersirat fungsi pendidikan nasional meliputi beberapa hal: yaitu 1) sebagai upaya pengembangan kemampuan bangsa; 2) pembentukan karakter serta peradaban bangsa yang bermartabat; 3) mencerdaskan kehidupan bangsa agar potensi peserta dapat berkembang menuju manusia memiliki iman dan taqwa kepada Tuhan yang Maha Esa, berakhlakul karimah, sehat, berilmu, cakap, kreatif, serta mandiri; 4) menjadi warga Negara yang demokratis serta bertanggung jawab. ${ }^{2}$

Dalam perkembangan selanjutnya, pendidikan diartikan sebagai usaha yang dijalankan oleh seseorang atau sekelompok orang untuk mempengaruhi seseorang atau sekelompok orang agar menjadi dewasa atau mencapai tingkat hidup dan penghidupan

\footnotetext{
${ }^{1}$ Benediktus Vito and Hetty Krisnani, 'Kesenjangan pendidikan desa dan kota', Prosiding Penelitian dan Pengabdian kepada Masyarakat, vol. 2, no. 2 (2015); Nadziroh Nadziroh, Chairiyah Chairiyah, and Wachid Pratomo, 'Hak Warga Negara dalam Memperoleh Pendidikan Dasar di Indonesia', Trihayu, vol. 4, no. 3 (Sarjanawiyata Tamansiswa University, 2018); Lukman Hakim, 'Pemerataan Akses Pendidikan Bagi Rakyat Sesuai Dengan Amanat Undang-Undang Nomor 20 Tahun 2003 Tentang Sistem Pendidikan Nasional', EduTech: Jurnal Ilmu Pendidikan dan Ilmu Sosial, vol. 2, no. 1 (2016).

${ }^{2}$ R.I. Undang-Undang, 'No. 20 Tahun 2003 Tentang Sistem Pendidikan Nasional. 2003', Jakarta: Sinar Grafika (2013).
} 
yang lebih tinggi dalam arti mental. ${ }^{3}$ Pendidikan juga diartikan sebagai suatu proses pembelajaran kepada peserta didik (manusia) agar menjadi manusia yang cerdas dan dewasa seutuhnya. ${ }^{4}$

Sementara pembelajaran mengandung pengertian "proses, cara, perbuatan menjadikan orang atau makhluk hidup belajar". 5 Pembelajaran merupakan proses interaksi yang terjadi antara peserta didik dengan lingkungannya, sehingga mengalami perubahan perilaku ke arah yang lebih baik. Berbagai macam faktor memiliki andil dalam mempengaruhi interaksi tersebut, baik faktor internal yang berasal dari diri individu, maupun faktor eksternal yang bersumber dari lingkungan. ${ }^{6}$

Faktor-faktor yang mempengaruhi belajar setidaknya terbagi kepada dua jenis, yaitu faktor intern dan faktor ekstern. Faktor intern adalah faktor yang muncul pada diri individu, dalam hal ini adalah peserta didik, sedangkan faktor ekstern adalah faktor dari luar diri peserta didik. ${ }^{7}$ Faktor intern terbagi tiga yaitu: faktor jasmaniah, psikologi dan kelelahan. Di antara faktor intern yang sangat mempengaruhi peserta didik adalah faktor psikologi yang meliputi intellegensia (kecerdasan), minat, perhatian, motif, bakat, maupun kematangan dan kesiapan dalam belajar. Adapun di antara faktor ekstern yang sangat mempengaruhi adalah: faktor sekolah, faktor keluarga, dan faktor masyarakat.

Berdasarkan beberapa faktor tersebut di atas menunjukkan bahwa belajar merupakan proses yang cukup memiliki kompleksitas. Dengan kata lain pelaksanaan dan hasil belajar sangat ditentukan oleh beragam faktor tersebut. Kesuksesan siswa dalam belajar sangat dipengaruhi oleh keberadaan faktor-faktor tersebut baik faktor yang mendukung maupun faktor yang menghambat kegiatan belajar. Sebagaimana dijelaskan di atas, faktor sekolah adalah salah satu faktor ekstern yang sangat

\footnotetext{
${ }^{3}$ Ilmu Pendidikan Islam Ramayulis, Kalam Mulia (Jakarta, 2008). hlm. 13

${ }^{4}$ Ahmad Susanto, Pemikiran Pendidikan Islam (Amzah, 2009). hlm. 1

${ }^{5}$ Tim Penyusun Kamus Besar Bahasa Indonesia, 'Kamus besar bahasa Indonesia', Jakarta: Balai Pustaka (2008).

${ }^{6}$ M.A. Muhaimin and Nur Ali, 'Paradigma Pendidikan Islam', Bandung, Rosda Karya (2002); Enco Mulyasa, Kurikulum berbasis kompetensi: konsep, karakteristik, dan implementasi (PT Remaja Rosdakarya, 2002).

${ }^{7}$ Belajar Dan Faktor-Faktor Yang Slameto, 'Mempengaruhinya', Jakarta: Rineka cipta (2003). hlm. 54
} 
|SYARIFAH | Profil dan Kompetensi Guru Bahasa Arab...

mempengaruhi belajar. ${ }^{8}$ Faktor sekolah meliputi: Pendidik (guru), lingkungan belajar, metode dan lain sebagainya.

Bahasa Arab merupakan mata pelajaran yang cenderung dianggap sulit di kalangan siswa baik di sekolah maupun madrasah. Bahasa Arab adalah mata pelajaran wajib yang harus diajarkan di semua Madrasah Aliyah. Thu'aimah dan an-Naqah dalam Muradi menyebutkan bahwa tujuan pembelajaran bahasa Arab bagi non-Arab adalah: 1) memiliki pemahaman yang benar terhadap bahasa Arab, sehingga secara sadar mampu menyimak kondisi-kondisi kehidupan secara umum; 2) memiliki kemampuan berbicara menggunakan bahasa Arab sebagai media komunikasi langsung dan ekspresi jiwa. 3) mampu membaca teks berbahasa Arab dengan mudah, sehingga mampu menemukan makna-makna dan berinteraksi dengan teks-teks tersebut. 4) mampu menulis menggunakan bahasa Arab sebagai media dalam mengekspresikan diri dan berbagai kondisi fungsional lainnya. ${ }^{9}$

Permasalahan dalam belajar bahasa Arab terdiri dari aspek linguistik dan non linguistik. Aspek linguistik terdiri atas: problematika pada unsur bunyi (fonetik), tulisan, kosa kata, pembentukan kata (morfologi), tata bahasa (sintaksis), dan ilmu tentang makna (semantik), sedangkan problematika pada aspek non linguistik dapat muncul dari unsur guru/pendidik, peserta didik, kesesuaian materi ajar dan kelengkapan media atau sarana prasarana yang digunakan dalam belajar, serta perbedaan sosiokultural antara Indonesia dan Arab yang berdampak pada pembelajaran bahasa Arab. ${ }^{10}$ Selain itu jumlah jam pelajaran bahasa Arab yang kurang memadai juga menimbulkan kesan bahwa bahasa Arab tidak atau kurang penting dibandingkan bahasa Inggris. ${ }^{11}$ Belajar bahasa Arab juga seringkali hanya dengan motif keagamaan, ${ }^{12}$ yaitu untuk mendalami teks-teks keagamaan sehingga seringkali dianggap kurang menarik. Faktor lain yang menyebabkan rendahnya motivasi siswa dalam belajar bahasa Arab

\footnotetext{
${ }^{8}$ Hendra Dani Saputra, Faisal Ismet, and Andrizal Andrizal, 'Pengaruh Motivasi Terhadap Hasil Belajar Siswa SMK', Invotek: Jurnal Inovasi Vokasional dan Teknologi, vol. 18, no. 1 (2018), pp. 25-30.

${ }^{9}$ Ahmad Muradi, 'Tujuan Pembelajaran Bahasa Asing (Arab) Di Indonesia', Jurnal Al Maqayis, vol. 1, no. 1 (2014).

${ }^{10}$ Noor Amirudin, 'Problematika Pembelajaran Bahasa Arab', TAMADDUN (2017), pp. 1-12.

${ }^{11}$ M.O.H. AININ, 'Pembelajaran Bahasa Arab motivasional', Prosiding Konfererensi Nasional Bahasa Arab, vol. 1, no. 1 (2015).

${ }^{12}$ Dony Handriawan, 'Mempertegas Kembali Arah Pembelajaran Bahasa Arab: Perspektif Budaya terhadap Tradisi Belajar Bahasa Arab di Indonesia" dalam Al-Mahāra’, Jurnal Al-Mahara, vol. 1, no. 1 (2015), pp. 43-64.
} 
adalah: kompleksitas bahasa Arab, materi yang diajarkan dan metode yang digunakan oleh guru; kesiapan fasilitas dan sarana belajar; dan yang tidak kalah pentingnya adalah faktor kepribadian guru. ${ }^{13}$ Berbagai faktor tersebut harus menjadi perhatian agar dapat menciptakan pembelajaran bahasa Arab yang menyenangkan dan juga dapat meningkatkan motivasi siswa.

Pencapaian hasil belajar bahasa Arab di tingkat Madrasah Aliyah berimbas pada tingkat pendidikan selanjutnya yaitu perguruan tinggi. Oleh sebab itu keberhasilan pembelajaran bahasa Arab di jenjang perguruan tinggi sangat ditentukan oleh pendidikan bahasa Arab di Madrasah Aliyah. Karena kemampuan dasar bahasa Arab sangat membantu dalam pencapaian hasil belajar bahasa Arab di perguruan tinggi. Berdasarkan uraian di atas, faktor guru adalah salah satu faktor yang sangat mempengaruhi ketercapaian tujuan dalam pembelajaran bahasa Arab di Madrasah Aliyah. Di lapangan, masih banyak ditemukan guru bahasa Arab yang tidak memiliki kualifikasi pendidikan Sarjana/Magister PBA (Pendidikan Bahasa Arab), ${ }^{14}$ atau dengan kata lain tidak linier dengan latar belakang keahliannya.

Guru sebagai sumber daya pendidikan memiliki peran yang sangat strategis dalam membentuk karakter bangsa melalui pengembangan diri dan nilai-nilai yang diinginkan. Salah satu upaya yang dilakukan dalam memaksimalkan peran guru di sekolah agar dapat berfungsi secara efektif dan efisien adalah dengan mendeskripsikan profil guru ideal sesuai peraturan yang berlaku. Profil guru ideal meliputi: kompetensi kompetensi pedagogik, kepribadian, kompetensi social, dan kompetensi profesional.

Berdasarkan fenomena tersebut, penulis merasa tergugah untuk meneliti tentang "Profil dan Kompetensi Guru Bahasa Arab Madrasah Aliyah Negeri di Provinsi Kepulauan Bangka Belitung”, karena hal tersebut bisa dijadikan salah satu masukan bagi Kementerian Agama sebagai bahan pertimbangan untuk memperbaiki kinerja guru bahasa Arab di Madrasah Aliyah sehingga output yang dikeluarkan sudah memiliki capaian sebagaimana yang ditetapkan oleh Kementerian Agama.

\footnotetext{
${ }^{13}$ Asep Muhammad Saepul Islam, 'Faktor Demotivasi Pembelajaran Bahasa Arab dalam Perspektif Siswa Madrasah', Arabiyât: Jurnal Pendidikan Bahasa Arab dan Kebahasaaraban, vol. 2, no. 1 (2015), pp. 1-16.

${ }^{14}$ Imam Makruf, 'Manajemen Integrasi Pembelajaran Bahasa Arab di Madrasah Berbasis Pondok Pesantren', Cendekia: Jurnal Kependidikan Dan Kemasyarakatan, vol. 14, no. 2 (2016), pp. 265-80.
} 
Penulisan artikel ini bertujuan untuk memaparkan tentang Profil Guru Bahasa Arab Madrasah Aliyah di Provinsi Kepulauan Bangka Belitung, relevansi latar belakang keilmuan Guru Bahasa Arab, serta Kompetensi Guru Bahasa Arab ditinjau dari persektif siswa. Madrasah Aliyah Negeri yang dijadikan obyek penelitian dibatasi pada MAN 1 Pangkalpinang, MAN 1 Bangka, dan MAN IC Bangka Tengah. Metode penelitian yang digunakan adalah kuantitatif dengan pendekatan deskriptif. Jumlah sample sebanyak 310 responden dari total populasi 1.600 responden. Pengambilan sample menggunakan teknik Krecjie dan Morgan. ${ }^{15}$

\section{B. Profil dan Kompetensi Guru}

Dalam pendidikan Islam, guru memiliki arti dan peranan yang sangat penting. ${ }^{16}$ Guru adalah orang tua siswa di sekolah. Oleh sebab itu guru memiliki tanggung jawab ${ }^{17}$ dan andil yang besar dalam menentukan arah pendidikan siswanya. ${ }^{18}$ Islam sangat menghargai dan menghormati seorang guru, karena guru (pendidik) adalah orang yang berilmu pengetahuan. ${ }^{19}$ Dalam Alqur'an sangat jelas disebutkan bahwa Allah mengangkat derajat dan memuliakan orang-orang yang memiliki ilmu pengetahuan dibandingkan orang-orang yang tidak berilmu pengetahuan dan bukan pendidik. $^{20}$ Dalam pendidikan tradisional Islam, guru diposisikan begitu terhormat. ${ }^{21}$ Guru diposisikan sebagai orang yang berilmu, jauh dari perbuatan dosa, shalih, dan sosok teladan, sehingga guru dituntut untuk mengaktualisasi keilmuan yang dimilikinya dengan beramal saleh. ${ }^{22}$ Selain itu, guru juga dianggap bertanggung jawab terhadap para

\footnotetext{
${ }^{15}$ Chua Lee Chuan and Jabatan Penyelidikan, 'Sample size estimation using Krejcie and Morgan and Cohen statistical power analysis: A comparison', Jurnal Penyelidikan IPBL, vol. 7, no. 1 (2006), pp. $78-86$.

${ }^{16}$ Saifullah Idris and Z.A. Tabrani, 'Realitas Konsep Pendidikan Humanisme dalam Konteks Pendidikan Islam', Jurnal Edukasi: Jurnal Bimbingan Konseling, vol. 3, no. 1 (2017), pp. 96-113.

${ }^{17}$ Ismail Darimi, 'Peningkatan Kompetensi Pedagogik Guru PAI dalam Pembelajaran', Jurnal MUDARRISUNA: Media Kajian Pendidikan Agama Islam, vol. 5, no. 2 (2015), pp. 309-24. Edukatif (2013).

${ }^{18}$ Warih Jatirahayu, 'Guru Berkualitas Kunci Mutu Pendidikan', Jurnal Ilmiah Guru Caraka Olah Pikir

${ }^{19}$ Sutarman Sutarman, 'Guru dan Peserta Didik dalam Perspektif Pendidikan Islam', Al-Misbah (Jurnal Islamic Studies), vol. 5, no. 1 (2019), pp. 34-50; Ahmad Junaedy Abu Huraerah, 'Etika Guru dalam Perspektif alTimidzi (Studi Atas Kitab Sunan al-Tirmidzi Karya Abu Isa Muhammad Bin Isa al-Tirmidzi)', Journal of Islamic Education Policy, vol. 1, no. 2 (2017).

${ }^{20}$ Muhammad Sudiyono, 'Ilmu Pendidikan Islam', Jakarta: Rineka Cipta (2009). hlm. 134

${ }^{21}$ M. Suardi, 'Pengaruh Kepribadian Guru PAI terhadap Hasil Belajar Siswa di Sekolah', IQRO: Journal of Islamic Education, vol. 1, no. 2 (2018), pp. 121-8.

${ }^{22}$ A. Marjuni, 'Tanggung Jawab Guru Dalam Pengembangan Kompetensi Profesional', Inspiratif Pendidikan, vol. 5, no. 1 (2016), pp. 116-26; J. Hasnawati, 'Implementasi Kompetensi Profesionalisme Guru dalam Pengembangan Kinerja Pembelajaran’, Inspiratif Pendidikan, vol. 5, no. 1 (2016), pp. 77-93.
} 
siswanya, tidak hanya pada kegiatan belajar dan mengajar tetapi juga di luar jam pelajaran, ${ }^{23}$ bahkan sampai akhirat. ${ }^{24}$ Sehingga, sudah menjadi kewajiban seorang guru untuk mengajarkan dan mengamalkan ilmunya. Jika kewajiban ini dikerjakan, maka pahalanya akan terus mengalir selama ilmu yang diajarkan tersebut masih diamalkan oleh orang yang belajar, karena mendidik dan mengajar merupakan salah satu dari amal jariyah. $^{25}$

Guru adalah pendidik profesional yang peran utamanya adalah mendidik, mengajar, membimbing, mengarahkan, melatih, menilai, dan mengevaluasi peserta didik baik pada pendidikan usia dini (jalur pendidikan formal) maupun pendidikan dasar dan menengah. ${ }^{26}$ Profesional adalah pekerjaan atau kegiatan yang dilakukan oleh seseorang yang memerlukan keahlian, kecakapan atau kemahiran yang memenuhi standar mutu atau norma tertentu serta memerlukan pendidikan profesi sehingga dapat menjadi sumber penghasilan. ${ }^{27}$ Menurut Wina Sanjaya syarat pokok guru profesional adalah: (1) profesi tersebut harus ditunjang oleh suatu ilmu tertentu secara mendalam dari lembaga pendidikan yang sesuai, sehingga kinerjanya didasarkan kepada keilmuan yang dimilikinya yang dapat dipertanggung jawabkan secara ilmiah; (2) suatu profesi menekankan kepada suatu keahlian dalam bidang tertentu yang spesifik sesuai dengan jenis profesinya, sehingga antara profesi yang satu dengan yang lainnya dapat dipisahkan secara tegas; (3) tingkat kemampuan dan keahlian suatu profesi didasarkan kepada kualifikasi akademik yang dilaluinya dan diakui oleh masyarakat, sehingga semakin tinggi kualifikasi akademik yang sesuai dengan profesinya, semakin tinggi pula tingkat keahliannya dan semakin tinggi pula tingkat penghargaan yang diterimanya; (4) suatu profesi selain dibutuhkan oleh masyarakat juga memiliki dampak terhadap sosial kemasyarakatan, sehingga masyarakat memiliki kepekaan yang sangat tinggi terhadap efek yang ditimbulkan dari pekerjaan profesinya. Sebagai suatu profesi, kompetensi

\footnotetext{
${ }^{23}$ Juhji Juhji, 'Peran Urgen Guru dalam Pendidikan', Studia Didaktika, vol. 10, no. 01 (2016), pp. 51-62.

${ }^{24}$ Ngainun Naim, Menjadi guru inspiratif: memberdayakan dan mengubah jalan hidup siswa (Pustaka pelajar, 2009). hlm. 5

${ }^{25}$ Muhammad Muntahibun, 'Ilmu Pendidikan Islam', Yogyakarta: Teras (2011). hlm. 112.

${ }^{26}$ Harpani Matnuh, 'Perlindungan Hukum profesionalisme Guru', Jurnal Pendidikan Kewarganegaraan, vol. 7, no. 2 (2017), pp. 46-50; Hamid Darmadi, 'Tugas, Peran, Kompetensi, dan Tanggung Jawab Menjadi Guru Profesional', Edukasi: Jurnal Pendidikan, vol. 13, no. 2 (2016), pp. 161-74.

${ }^{27}$ Nila Kesumawati, 'Profesionalisme dan Kesejahteraan Guru', Jurnal Dosen Universitas PGRI Palembang (2015); Darmadi, 'Tugas, Peran, Kompetensi, dan Tanggung Jawab Menjadi Guru Profesional'; Abdul Hamid, 'Guru Profesional', Al-Falah: Jurnal Ilmiah Keislaman dan Kemasyarakatan, vol. 17, no. 2 (2017), pp. 27485.
} 
|SYARIFAH | Profil dan Kompetensi Guru Bahasa Arab...

yang harus dimiliki oleh seorang guru, yaitu kompetensi pribadi, kompetensi profesional dan kompetensi sosial kemasyarakatan. ${ }^{28}$

Sebagai agen pembelajaran, ${ }^{29}$ guru di Indonesia harus memenuhi tiga persyaratan sebagaimana dijelaskan oleh Muchlas Samani, yaitu meliputi kualifikasi pendidikan minimum, kompetensi, dan sertifikasi sebagai pendidik profesional. Ketiga persyaratan untuk menjadi guru tersebut sesuai dengan Undang-Undang Guru dan Dosen Pasal 1 butir 12, yaitu bahwa sertifikat pendidik merupakan bukti formal sebagai pengakuan yang diberikan kepada guru dan dosen sebagai tenaga profesional. Sementara itu, pada Pasal 11 ayat (1) juga disebutkan bahwa sertifikat pendidik diberikan kepada guru yang telah memenuhi persyaratan. Untuk itu, guru dapat memperoleh sertifikat pendidik jika telah memenuhi dua syarat, yaitu kualifikasi pendidikan minimum yang ditentukan (diploma-D4/sarjana S1) dan terbukti telah menguasai kompetensi tertentu. Untuk itu, sebenarnya syarat untuk menjadi guru hanya ada dua, yaitu kualifikasi akademik minimum (ijazah D4/S1) dan penguasaan kompetensi minimal sebagai guru yang dibuktikan dengan sertifikat pendidik. ${ }^{30}$

Dalam meningkatkan mutu pendidikan indikator profil guru profesional yaitu; (1) memiliki kematangan kepribadian dan berkembang, (2) memiliki penguasaan ilmu yang mendalam, (3) memiliki keterampilan dalam membangkitkan motivasi peserta didik terhadap sains dan teknologi, dan (4) melakukan pengembangan profesi secara berkelanjutan. Keempat aspek tersebut merupakan satu kesatuan utuh yang tidak dapat dipisahkan dan ditambah dengan upaya lain yang ikut mempengaruhi perkembangan profesi guru yang profesional. ${ }^{31}$

Tugas dan tanggung jawab tersebut tidak dapat dilakukan oleh orang yang tidak memiliki keahlian untuk melakukan kegiatan atau profesi sebagai guru. Untuk menjadi guru apalagi seorang guru yang ideal dibutuhkan syarat-syarat khusus, terutama harus mengetahui seluk-beluk pendidikan dan pengajaran. Adapun syarat-syarat yang harus

\footnotetext{
${ }^{28}$ Sanjaya Wina, 'Pembelajaran dalam Implementasi Kurikulum Berbasis Kompetensi', Jakarta: Kencana Prenada Media Group (2005). hlm. 142-143 1 (2016).

${ }^{29}$ Lita Latiana, 'Peran Sertifikasi Guru dalam Meningkatkan Profesionalisme Pendidik', Edukasi, vol. 1, no.

${ }^{30}$ Muchlas Samani and Muchlas Samani, Mengenal sertifikasi guru di Indonesia (Diterbitkan bersama oleh Penerbit SIC dan Asosiasi Peneliti Pendidikan Indonesia, 2006). hlm. 7

${ }^{31}$ Ibid.; Edi Hendri, 'Guru berkualitas: profesional dan cerdas emosi', Jurnal saung guru, vol. 1, no. 2 (2010), p. 1.
} 
dimiliki seorang guru profesional berdasarkan Undang-undang Guru dan Dosen pada bab IV bagian kesatu adalah sebagaimana berikut: (1) Guru harus memiliki kualifikasi akademik, kompetensi, sertifikat pendidik, sehat jasmani dan rohani serta memiliki kemampuan untuk mewujudkan tujuan pendidikan nasional; Kualifikasi akademik diperoleh melalui pendidikan tinggi program sarjana atau program diploma empat; (2) Kompetensi guru meliputi kompetensi pedagogik, kompetensi kepribadian, kompetensi sosial dan kompetensi profesional yang diperoleh melalui pendidikan profesi; (3) Sertifikat pendidik diberikan kepada guru yang telah memenuhi persyaratan yang penyelenggaraan sertifikasinya oleh perguruan tinggi yang memiliki program pengadaan tenaga kependidikan yang terakreditasi dan ditetapkan oleh pemerintah. Sertifikasi ini dilaksanakan secara obyektif, transparan dan akuntabel. ${ }^{32}$

Guru merupakan ujung tombak pembaharuan yang memiliki tugas memantau atau mengembangkan pembelajaran, mendukung norma-norma dalam masyarakat, menciptakan kondisi belajar yang baik serta menjamin keberhasilan pendidikan, oleh sebab itu guru harus meningkatkan kompetensi yang dimilikinya. Berdasarkan Peraturan Menteri Pendidikan Nasional Republik Indonesia Nomor 16 Tahun 2007 tentang Standar Kualifikasi Akademik dan Kompetensi Guru, Standar Kompetensi yang harus dipenuhi seorang Guru dikembangkan secara utuh dari empat kompetensi utama yang meliputi: (1) kompetensi pedagogik, (2) kepribadian, (3) sosial, dan (4) profesional. ${ }^{33}$ Keempat kompetensi tersebut harus diintegrasikan dalam kinerja guru. Secara rinci, empat kompetensi yang harus dimiliki seorang guru adalah sebagai berikut:

a. Kompetensi Pedagogik

Kompetensi pedagogik yaitu kemampuan yang harus dimiliki guru berkenaan dengan karakteristik siswa dilihat dari berbagai aspek seperti moral, emosional, dan intelektual. ${ }^{34}$ Hal tersebut berimplikasi pada keharusan seorang guru untuk memiliki kemampuan dalam penguasaan teori dan prinsip-prinsip belajar, karena siswa

\footnotetext{
${ }^{32}$ Kementerian Pendidikan Nasional RI, Undang-Undang RI No. 14 Tahun 2005 tentang Guru dan Dosen (BP. Cipta jaya, 2019).

${ }^{33}$ Pemerintah Republik Indonesia, Undang Undang Republik Indonesia No. 16 Tahun 2007 tentang Standar Kualifikasi Guru dan Dosen (Jakarta, 2003); Muhammad Nasrul Waton, 'Sertifikasi Guru menuju Profesionalisme Pendidik', Tafáqquh: Jurnal Penelitian Dan Kajian Keislaman, vol. 4, no. 1 (2016), pp. 1-11.

${ }^{34}$ Saiful Bahri, 'Supervisi akademik dalam peningkatan profesionalisme guru', Visipena Journal, vol. 5, no. 1 (2014), pp. 100-12.
} 
memiliki karakter, sifat, dan ketertarikan yang berbeda. ${ }^{35}$ Seorang guru juga harus mampu mengembangkan kurikulum tingkat satuan pendidikan masing-masing yang disesuaikan dengan kebutuhan lokal.

Guru harus mampu mengoptimalkan potensi peserta didik dalam mengaktualisasikan kemampuannya di kelas, dan harus mampu melakukan evaluasi terhadap kegiatan pembelajaran yang telah dilakukan. Kemampuan yang harus dimiliki guru berkenaan dengan aspek-aspek berikut, yaitu: (1) penguasaan terhadap karakteristik peserta didik dari aspek fisik, moral, sosial, kultural, emosional dan intelektual; (2) penguasaan terhadap teori belajar dan prinsip-prinsip pembelajaran yang mendidik; (3) memiliki kemampuan dalam mengembangkan kurikulum yang berhubungan dengan bidang pengembangan yang diampu; (4) menyelenggarakan kegiatan pengembangan yang mendidik; (5) memanfaatkan teknologi informasi dan komunikasi dalam penyelenggaraan kegiatan pengembangan yang mendidik; (6) memfasilitasi peserta didik dalam mengaktualisasikan berbagai potensi yang dimiliki; (7) memiliki kemampuan berkomunikasi secara efektif, empatik, dan santun dengan peserta didik; (8) memiliki kemampuan dalam mengevaluasi proses dan hasil belajar; (9) memanfaatkan hasil evaluasi untuk kepentingan pembelajaran, dan (10) melakukan tindakan reflektif untuk peningkatan kualitas pembelajaran. ${ }^{36}$

b. Kompetensi Kepribadian

Guru harus memiliki rasa bangga dalam melaksanakan tugas yang dipercayakan kepadanya dalam mempersiapkan generasi masa depan yang berkualitas. Guru juga harus tegar dalam melaksanakan tugas walaupun menghadapi tantangan dan rintangan yang berat. Pendidikan adalah proses yang direncanakan agar semua berkembang melalui proses pembelajaran. Sebagai pendidik, guru harus mampu mempengaruhi perkembangan peserta didik agar sesuai dengan tata nilai yang dianggap baik dan berlaku dalam masyarakat.

Tata nilai termasuk norma, moral, estetika, dan ilmu pengetahuan mempengaruhi etika siswa sebagai seorang individu maupun sebagai bagian dari masyarakat. Penerapan

\footnotetext{
${ }^{35}$ Ahmad Yanizon and Nellida Purba, 'Hubungan antara Sikap Orang Tua dengan Minat Belajar Siswa', KOPASTA: Jurnal Program Studi Bimbingan Konseling, Vol. 4, No. 1 (2017).

${ }^{36}$ Indonesia, Undang Undang Republik Indonesia No. 16 Tahun 2007 tentang Standar Kualifikasi Guru dan Dosen.
} 
disiplin yang baik dalam proses pendidikan akan menghasilkan sikap mental, watak dan kepribadian siswa yang kuat. Guru dituntut harus mampu membelajarkan siswanya tentang disiplin diri, belajar membaca, mencintai buku, menghargai waktu, belajar bagaimana cara belajar, mematuhi aturan atau tata tertib, dan belajar bagaimana harus berbuat. Semuanya itu akan berhasil apabila guru juga disiplin dalam melaksanakan tugas dan kewajibannya.

Guru harus mempunyai kemampuan yang berkaitan dengan kemantapan dan integritas kepribadian seorang guru sebagaimana berikut: (1) bertindak sesuai dengan norma agama, hukum, sosial, dan kebudayaan nasional Indonesia; (2) menampilkan diri sebagai pribadi yang jujur, berakhlak mulia, dan teladan bagi peserta didik dan masyarakat; (3) menampilkan diri sebagai pribadi yang mantap, stabil, dewasa, arif, dan berwibawa; (4) menunjukkan etos kerja, tanggung jawab yang tinggi, rasa bangga menjadi guru, dan rasa percaya diri, dan (5) menjunjung tinggi kode etik profesi guru. ${ }^{37}$

c. Kompetensi Sosial

Guru di mata masyarakat dan siswa merupakan panutan yang perlu dicontoh dan diteladani dalam kehidupan sehari-hari. Guru harus memiliki kemampuan sosial dengan masyarakat, dalam rangka pelaksanaan proses pembelajaran yang efektif. Dengan memiliki kemampuan tersebut, otomatis hubungan sekolah dengan masyarakat akan berjalan dengan lancar, sehingga jika ada keperluan dengan orang tua siswa, para guru akan mendapatkan kemudahan.

Kemampuan sosial meliputi: kemampuan guru dalam berkomunikasi, bekerja sama, bergaul simpatik, dan mempunyai jiwa yang menyenangkan. Kriteria kinerja guru yang harus dilakukan adalah: (1) bertindak objektif serta tidak diskriminatif berdasarkan jenis kelamin, agama, ras, kondisi fisik, latar belakang keluarga, dan status sosial ekonomi; (2) memiliki kemampuan berkomunikasi secara efektif, empatik, dan santun dengan sesama pendidik, tenaga kependidikan, orang tua, dan masyarakat; (3) memiliki kemampuan beradaptasi di tempat bertugas di seluruh wilayah Republik Indonesia yang memiliki keragaman sosial budaya; dan (4)

\footnotetext{
${ }^{37}$ Ibid.
} 
|SYARIFAH | Profil dan Kompetensi Guru Bahasa Arab...

memiliki kemampuan berkomunikasi dengan komunitas profesi sendiri dan profesi lain secara lisan dan tulisan atau bentuk lain. ${ }^{38}$

d. Kompetensi Profesional

Kompetensi Profesional yaitu kemampuan yang harus dimiliki guru dalam perencanaan dan pelaksanaan proses pembelajaran. Guru mempunyai tugas untuk mengarahkan kegiatan belajar siswa untuk mencapai tujuan pembelajaran, untuk itu guru dituntut mampu menyampaikan bahan pelajaran. Guru harus selalu mengupdate, dan menguasai materi pelajaran yang disajikan. Persiapan diri tentang materi diusahakan dengan jalan mencari informasi melalui berbagai sumber seperti membaca buku-buku terbaru, mengakses dari internet, selalu mengikuti perkembangan dan kemajuan terkini tentang materi yang disajikan.

Kompetensi atau kemampuan kepribadian yaitu kemampuan yang harus dimiliki guru berkenaan dengan aspek berikut: (1) memiliki penguasaan materi, struktur, konsep, dan pola pikir keilmuan yang mendukung mata pelajaran yang diampu; (2) memiliki penguasaan terhadap standar kompetensi dan kompetensi dasar mata pelajaran atau bidang pengembangan yang diampu; (3) mampu melakukan pengembangan materi ajar secara kreatif; (4) selalu mengembangkan profesionalitas diri secara berkelanjutan dengan melakukan tindakan reflektif; dan (5) memiliki kemampuan dalam memanfaatkan teknologi informasi dan komunikasi untuk berkomunikasi dan mengembangkan diri. ${ }^{39}$

Empat kompetensi tersebut di atas menjelaskan indikator-indikator guru profesional dengan sangat gamblang. Untuk mewujudkan profesionalitas seorang guru sangat diperlukan adanya kerjasama antara orangtua siswa, pimpinan sekolah, masyarakat sekitar dan bahkan dengan siswa yang dihadapi sehari-hari. ${ }^{40}$

Guru merupakan salah satu komponen manusiawi dalam proses belajar mengajar yang memiliki peran penting dalam usaha pembentukan sumber daya manusia yang potensial. Dalam unsur bidang pendidikan guru harus berperan akif dan menempatkan kedudukan sebagai tenaga profesional sesuai dengan tuntutan masyarakat dari waktu ke

\footnotetext{
${ }^{38}$ Ibid.

${ }^{39} \mathrm{Ibid}$.

${ }^{40}$ Nawawi Hadari, 'Organisasi Sekolah dan Pengelolaan Kelas Sebagai Lembaga Pendidikan', Jakarta: Gunung Agung (2002).
} 
waktu. Hal ini dapat diartikan bahwa setiap guru memiliki tanggung jawab dalam mendewasakan para siswa pada taraf kematangan tertentu. Dalam hal ini guru tidak hanya hanya sebagai pengajar yang hanya menstransfer ilmu pengetahuan, tetapi juga sebagai pendidik dan pembimbing yang mengarahkan dan menuntun siswa dalam belajar. $^{41}$

Dengan demikian jelaslah bahwa profesionalisme seorang guru sangat terkait dengan mutu pendidikan dan saling mempengaruhi proses pencapaian tujuan pendidikan. Jika guru memiliki profesionalisme yang tinggi dalam melakukan pekerjaannya, secara otomatis mutu pendidikan akan meningkat. Meningkatnya mutu dan kualitas pendidikan sangat berpengaruh pada masa depan peserta didik maupun bangsa dan negara.

Pendidik atau guru bahasa Arab sama halnya dengan guru pada pelajaran lainnya dituntut untuk memiliki profil ideal sebagaimana dijelaskan di atas. Ukuran keberhasilan pembelajaran bahasa Arab, yaitu tercapainya kemahiran atau ketrampilan berbahasa Arab pada diri siswa. Kemahiran tersebut seyogyanya sejalan dengan tujuan pembelajaran bahasa Arab itu sendiri. Agar tujuan pembelajaran dapat tercapat, maka diharapkan guru bahasa Arab juga memenuhi persyaratan guru ideal tersebut.

\section{Hasil Penelitian dan Pembahasan}

\section{Profil Guru Bahasa Arab Madrasah Aliyah di Provinsi Kepulauan Bangka Belitung}

Berdasarkan kualifikasi akademik, profil guru Bahasa Arab Madrasah Aliyah di Bangka Belitung adalah sebagai berikut:

Tabel 1. Kualifikasi Akademik Guru Bahasa Arab Berdasarkan Latar Belakang Pendidikan di MAN 1 Pangkalpinang

\begin{tabular}{cccl}
\hline No. & Latar Belakang Pendidikan & Jumlah & \multicolumn{1}{c}{ Keterangan } \\
\hline 1. & S1 Pendidikan Bahasa Arab & 6 & 1 orang memiliki pendidikan terakhir \\
& & & S2 Metodologi Pendidikan Islam \\
2. & Lainnya & 1 & S2 Manajemen Pendidikan Islam \\
\hline & Total & 7 & \\
\hline
\end{tabular}

\footnotetext{
${ }^{41}$ Ibid. hlm. 123
} 
|SYARIFAH | Profil dan Kompetensi Guru Bahasa Arab...

Berdasarkan tabel 1, jumlah guru bahasa Arab di MAN 1 Pangkalpinang sebanyak 7 orang, dengan rincian: kualifikasi akademik S1 Pendidikan Bahasa Arab sebanyak 6 orang (salah satunya berpendidikan terakhir S2 Metodologi Pendidikan Islam) dan S2 Manajemen Pendidikan Islam sebanyak 1 orang. Selanjutnya, profil guru bahasa Arab berdasarkan kualifikasi akademik di MAN IC Bangka Tengah adalah sebagaimana tabel 2 .

Tabel 2. Kualifikasi Akademik Guru Bahasa Arab Berdasarkan Latar Belakang Pendidikan di MAN Insan Cendekia Bangka Tengah

\begin{tabular}{cccl}
\hline No. & Latar Belakang Pendidikan & Jumlah & \multicolumn{1}{c}{ Keterangan } \\
\hline 1. & S1 Pendidikan Bahasa Arab & 1 & $\begin{array}{l}\text { Pendidikan terakhir S2 Metodologi } \\
\text { Pendidikan Islam }\end{array}$ \\
2. & Lainnya & 0 & \\
\hline \multicolumn{2}{c}{ Total } & $\mathbf{1}$ & \\
\hline
\end{tabular}

Berdasarkan tabel 2, jumlah guru bahasa Arab di MAN IC Bangka Tengah sebanyak 1 orang dengan kualifikasi akademik S1 Pendidikan Bahasa Arab (pendidikan tearkhir S2 Metodologi Pendidikan Islam). Adapun profil guru bahasa Arab berdasarkan kualifikasi akademik di MAN 1 Bangka adalah sebagai berikut;

Tabel 3. Kualifikasi Akademik Guru Bahasa Arab Berdasarkan Latar Belakang Pendidikan di MAN 1 Bangka

\begin{tabular}{|c|c|c|c|}
\hline No. & Latar Belakang Pendidikan & Jumlah & Keterangan \\
\hline 1. & S1 Pendidikan Bahasa Arab & 1 & \\
\hline 2. & Lainnya & 1 & S1 Pendidikan Agama Islam \\
\hline & Total & 2 & \\
\hline
\end{tabular}

Berdasarkan tabel 3, jumlah guru bahasa Arab di MAN IC Bangka Tengah sebanyak 2 orang dengan rincian: 1 orang memiliki kualifikasi akademik S1 Pendidikan Bahasa Arab dan 1 orang lainnya S1 Pendidikan Agama Islam. Secara umum, kualifikasi akademik guru bahasa Arab di Madrasah Aliyah di Bangka Belitung adalah sebagaimana tabel 4 . 
Tabel 4. Kualifikasi Akademik Guru Bahasa Arab Berdasarkan Latar Belakang Pendidikan di Bangka Belitung

\begin{tabular}{ccccc}
\hline \multirow{2}{*}{ No. } & \multirow{2}{*}{ Asal Madrasah } & \multicolumn{2}{c}{ Kualifikasi Akademik } & \multirow{2}{*}{ Keterangan } \\
\cline { 3 - 4 } & & S1 PBA & Lainnya & \\
\hline 1. & MAN 1 Pangkalpinang & 6 & 1 & S2 MPI \\
2. & MAN IC Bangka Tengah & 1 & 0 & \\
3. & MAN 1 Bangka & 1 & 1 & S1 PAI \\
\hline & Total & 8 & 2 & \\
\hline
\end{tabular}

Berdasarkan tabel 4 tersebut, prosentase guru bahasa Arab Madrasah Aliyah di Bangka Belitung yang berkualifikasi akademik S1 PBA sebanyak $8(80 \%)$ orang dari total 10 orang, dan 2 (20\%) orang bukan S1 PBA. Adapun jika ditinjau dari sertifikat pendidik, profil guru bahasa Arab di MAN 1 Pangkalpinang dapat dilihat pada tabel 5 berikut:

Tabel 5. Jumlah Guru Bahasa Arab MAN 1 Pangkalpinang Berdasarkan Sertifikat Pendidik

\begin{tabular}{|c|c|c|c|}
\hline No. & Jenis Sertifikasi & Jumlah & Keterangan \\
\hline 1. & Guru Bahasa Arab & 3 & \\
\hline 2. & Lainnya & 0 & \\
\hline 3. & Belum Tersertifikasi & 4 & \\
\hline & Total & 7 & \\
\hline
\end{tabular}

Berdasarkan tabel 4, jumlah guru Bahasa Arab yang sudah memiliki sertifikat pendidik sebagai guru bahasa Arab di MAN 1 Pangkalpinang adalah sebanyak 3 orang dari total 7 orang dengan persentase 43\%. Jumlah guru bahasa Arab yang memiliki sertifikat pendidik di MAN IC Bangka Tengah adalah sebagaimana tabel 6.

Tabel 6. Daftar Jumlah Guru Bahasa Arab MAN IC Bangka Tengah Berdasarkan Sertifikat Pendidik

\begin{tabular}{cccc}
\hline No. & \multicolumn{1}{c}{ Jenis Sertifikasi } & Jumlah & Keterangan \\
\hline 1. & Guru Bahasa Arab & 1 & \\
2. & Lainnya & 0 & \\
3. & Belum Tersertifikasi & 0 & \\
\hline & Total & 1 & \\
\hline
\end{tabular}


|SYARIFAH | Profil dan Kompetensi Guru Bahasa Arab...

Berdasarkan tabel 6, guru Bahasa Arab di MAN IC Bangka Tengah sudah memiliki sertifikat pendidik. Adapun Jumlah guru bahasa Arab yang memiliki sertifikat pendidik di MAN 1 Bangka adalah sebagaimana tabel 7 berikut:

Tabel 7. Daftar Jumlah Guru Bahasa Arab MAN 1 Bangka

Berdasarkan Sertifikat Pendidik

\begin{tabular}{cccc}
\hline No. & \multicolumn{1}{c}{ Jenis Sertifikasi } & Jumlah & Keterangan \\
\hline 1. & Guru Bahasa Arab & 2 & \\
2. & Lainnya & 0 & \\
3. & Belum Tersertifikasi & 0 & \\
\hline \multicolumn{4}{c}{ Total } \\
\hline
\end{tabular}

Berdasarkan tabel 7, jumlah guru Bahasa Arab yang sudah memiliki sertifikat pendidik sebagai guru bahasa Arab di MAN 1 Bangka sebanyak 100\%. Secara umum, jumlah guru bahasa Arab Madrasah Aliyah Negeri di Bangka Belitung yang memiliki sertifikat pendidik di MAN 1 Bangka adalah sebagaimana tabel 8 berikut:

Tabel 8. Daftar Jumlah Guru Bahasa Arab MAN di Bangka Belitung Berdasarkan Sertifikat Pendidik

\begin{tabular}{lcccc}
\hline & Asal Madrasah & \multicolumn{3}{c}{ Jenis Sertifikasi } \\
\cline { 3 - 5 } No. & & $\begin{array}{c}\text { Guru Bahasa } \\
\text { Arab }\end{array}$ & Lainnya & Belum Tersertifikasi \\
\hline 1. & MAN 1 Pangkalpinang & 3 & 0 & 4 \\
2. & MAN IC Bangka Tengah & 1 & 0 & 0 \\
3. & MAN 1 Bangka & 2 & 0 & 0 \\
\hline \multicolumn{2}{c}{ Total } & 6 & 0 & 4 \\
\hline
\end{tabular}

Berdasarkan tabel 8, dapat dilihat bahwa, guru bahasa Arab yang memiliki sertifikat pendidik sebagai guru bahasa Arab sebanyak 6 orang (60\%), sedangkan guru bahasa Arab belum tersertifikasi sebanyak 4 orang (40\%).

\section{Relevansi Latar Belakang Keilmuan Guru Bahasa Arab dengan Mata Pelajaran yang Diampu}

Guru bahasa Arab harus memenuhi beberapa persyaratan sebagaimana amanat Undang-Undang Guru dan Dosen pada Bab IV bagian kesatu. Syarat-syarat yang harus dimiliki seorang guru bahasa Arab antara lain adalah: memiliki kualifikasi akademik sarjana (S1) atau diploma empat (D-IV), kompeten di bidangnya, memiliki sertifikat 
pendidik, memiliki tubuh dan jiwa yang sehat serta mampu mewujudkan tujuan pendidikan nasional; Kompetensi yang harus dimiliki guru bahasa Arab meliputi kompetensi pedagogik, kompetensi kepribadian, kompetensi sosial dan kompetensi profesional yang diperoleh melalui pendidikan profesi; Sertifikasi pendidik diberikan kepada guru bahasa Arab yang telah memenuhi syarat. Sertifikasi pendidik diselenggarakan oleh perguruan tinggi yang telah ditetapkan pemerintah dengan beberapa kriteria tertentu. Sertifikasi ini diselenggarakan secara obyektif, transparan dan akuntabel. $^{42}$

Jika merujuk kepada undang-undang tersebut, seorang guru minimal memiliki kualifikasi akademik S1 atau D4 yang linier dengan bidang ilmu yang diampu. Dengan kata lain, seorang guru bahasa Arab setidaknya adalah Sarjana di bidang Pendidikan Bahasa Arab dan idealnya telah memiliki sertifikat pendidik.

Relevansi keilmuan guru bahasa Arab berdasarkan data latar belakang pendidikan pada tabel 7, dapat dilihat bahwa dari 7 orang guru Bahasa Arab di MAN 1 Pangkalpinang, 6 di antaranya memiliki latar belakang pendidikan S1 PBA, dan hanya 1 orang yang missmatch yaitu berlatar belakang S1 PAI dan S2 MPI dengan prosentase $86 \%$ relevan dan 0,14\% tidak relevan. Adapun untuk guru bahasa Arab di MAN IC Bangka Tengah berjumlah 1 orang dengan kualifikasi pendidikan S1 Pendidikan Bahasa Arab (Pendidikan terakhir S2 Metodologi Pendidikan Islam) dengan prosentase sebesar 100\%. Sedangkan guru bahasa Arab di MAN 1 Bangka berjumlah 2 orang, dengan kualifikasi keilmuan S1 PBA sebanyak 1 orang (50\%) dan S1 PAI sebanyak 1 orang (50\%). Secara umum, jumlah guru bahasa Arab yang sudah memiliki kualifikasi akademik S1 PBA sebanyak 8 orang $(80 \%)$ dan S1 dari bidang lainnya sebanyak 2 orang $(20 \%)$.

Sedangkan jika ditinjau dari relevansi keilmuan berdasarkan sertifikat pendidik, maka berdasarkan tabel 8, dapat dilihat bahwa guru Bahasa Arab MAN 1 Pangkalpinang yang memiliki sertifikat pendidik Guru Bahasa Arab sebanyak 3 orang (43\%), sedangkan guru bahasa Arab yang belum memiliki sertifikat pendidik sebanyak 4 orang (57\%). Adapun guru bahasa Arab di MAN IC Bangka Tengah sudah memiliki sertifikat pendidik sebanyak 1 orang (100\%). Guru bahasa Arab di MAN 1 Bangka yang

\footnotetext{
${ }^{42}$ RI, Undang-Undang RI No. 14 Tahun 2005 tentang Guru dan Dosen.
} 
| SYARIFAH | Profil dan Kompetensi Guru Bahasa Arab...

sudah memiliki sertifikat profesi sebanyak 2 orang (100\%). Secara umum, jumlah guru bahasa Arab yang sudah tersertifikasi sebagai guru bahasa Arab profesional sebanyak 6 orang $(60 \%)$ dan yang belum tersertifikasi sebanyak 4 orang (40\%).

\section{Kompetensi Guru Bahasa Arab Madrasah Aliyah Ditinjau dari Perspektif Siswa}

Pengumpulan data pada penelitian ini dibatasi pada tiga Madrasah Aliyah Negeri (MAN) yang terdapat di Bangka dengan total sampel sebanyak 310 orang. Deskripsi data meliputi nilai mean (rata-rata), median, modus, dan simpangan baku. Data kompetensi guru bahasa Arab di MAN 1 Pangkalpinang didapat nilai mean sebesar 2.86, median 3, modus 4, dan standar deviasi 0.97. Data kompetensi guru bahasa Arab di MAN IC bangka Tengah didapat nilai mean sebesar 2.85, median 3, modus 3, dan standar deviasi 0.95. Sedangkan data kompetensi guru bahasa Arab di MAN 1 Bangka didapat nilai mean sebesar 2.96, median 3, modus 4, dan standar deviasi 0.94.

a. Kompetensi Guru Bahasa Arab MAN 1 Pangkalpinang

Berdasarkan hasil pengolahan dan analisis data didapat bahwa siswa MAN 1 Pangkalpinang mempersepsikan kompetensi guru bahasa Arab sebesar 2.89 masuk pada kategori "Cukup". Adapun jika dilihat berdasarkan kompetensi, diketahui kompetensi pedagogik guru yang terendah dengan skor sebesar 2.61 pada kategori "Cukup". Dalam hal ini, siswa merasa bahwa guru kurang mampu memberikan upaya pengembangan atas kemampuan siswa. Skor pengembangan peserta didik tergolong "Kurang Baik" dengan skor sebesar 2.31. Secara rinci sebaran skor kompetensi guru bahasa Arab berdasarkan persepsi siswa disajikan pada tabel di bawah ini:

Tabel 9. Kompetensi Guru Bahasa Arab Ditinjau dari Persepsi Siswa MAN 1 Pangkalpinang

\begin{tabular}{clcc}
\hline No & \multicolumn{1}{c}{ Kompetensi Guru Bahasa Arab } & Rerata & Keterangan \\
\hline A & Kompetensi Pedagogik & $\mathbf{2 . 6 1}$ & Cukup \\
1 & Kemampuan Mengelola Pembelajaran & 2.81 & Cukup \\
2 & Kemampuan Merancang dan Melaksanakan Pembelajaran & 2.54 & Cukup \\
3 & Kemampuan Melaksanakan Evaluasi Pembelajaran & 2.78 & Cukup
\end{tabular}




\begin{tabular}{clcc}
\hline No & \multicolumn{1}{c}{ Kompetensi Guru Bahasa Arab } & Rerata & Keterangan \\
\hline 4 & Kemampuan Pengembangan Peserta Didik & 2.31 & Kurang Baik \\
B & Kompetensi Profesional & $\mathbf{2 . 9 7}$ & Cukup \\
1 & Kemampuan Penguasaan dan Pemahaman Materi & 3.04 & Cukup \\
2 & Kemampuan Mengelola Proses Pembelajaran dan Kelas & 2.91 & Cukup \\
C & Kompetensi Sosial & $\mathbf{2 . 9 8}$ & Cukup \\
1 & Kemampuan Komunikasi, Bekerjasama, Agama, dan & 2.98 & Cukup \\
& Budaya & & \\
D & Kompetensi Kepribadian & $\mathbf{3 . 0 0}$ & Cukup \\
1 & Keteladanan & 3.00 & Cukup \\
2 & Kedisiplinan & 3.00 & Cukup \\
\hline & & 2.89 & Cukup \\
\hline
\end{tabular}

Secara visual kompetensi guru bahasa Arab berdasarkan persepsi siswa MAN 1 Pangkalpinang digambarkan sebagai berikut:

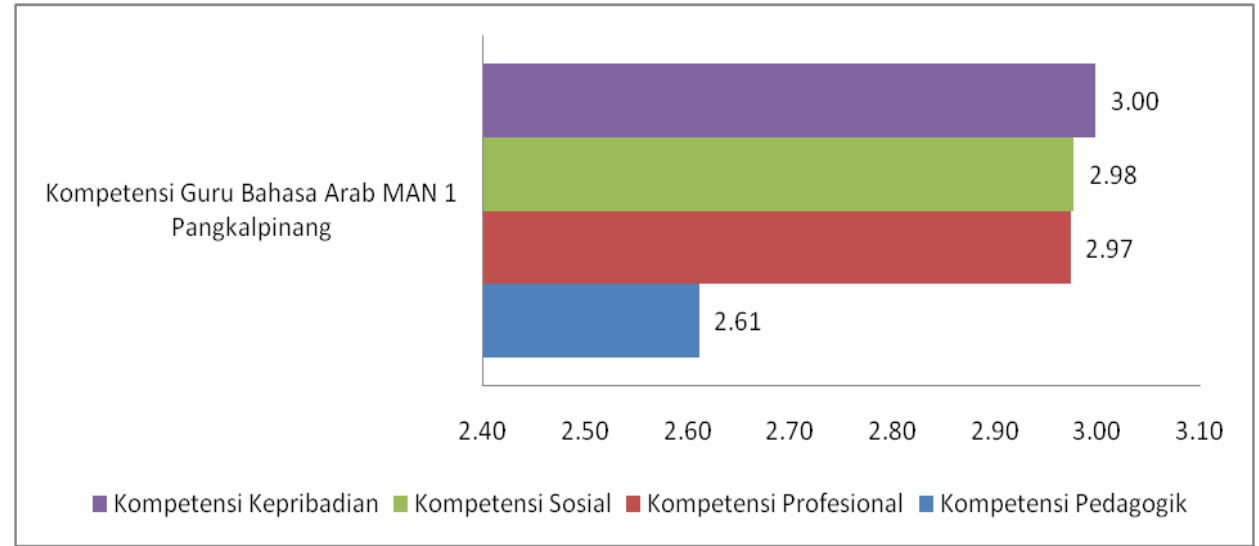

b. Kompetensi Guru Bahasa Arab MAN IC Bangka Tengah

Berdasarkan hasil pengolahan dan analisis data didapat bahwa siswa MAN IC Bangka Tengah mempersepsikan kompetensi guru bahasa Arab sebesar 2.89 masuk pada kategori "Cukup". Adapun jika dilihat berdasarkan kompetensi, diketahui kompetensi pedagogik guru yang terendah dengan skor sebesar 2.57 pada kategori "Cukup". Kemampuan pengembangan peserta didik kiranya perlu mendapat perhatian guru. Dalam hal ini, siswa merasa bahwa guru kurang mampu memberikan upaya pengembangan atas kemampuan siswa. Skor pengembangan peserta didik tergolong "Kurang Baik" dengan skor sebesar 2.20. Secara rinci sebaran skor kompetensi guru bahasa Arab berdasarkan persepsi siswa dapat disajikan pada tabel di bawah ini: 
|SYARIFAH | Profil dan Kompetensi Guru Bahasa Arab...

Tabel 10. Kompetensi Guru Bahasa Arab Ditinjau dari Persepsi Siswa MAN IC Bangka Tengah

\begin{tabular}{clcc}
\hline No & \multicolumn{1}{c}{ Kompetensi Guru Bahasa Arab } & Rerata & Keterangan \\
\hline A & Kompetensi Pedagogik & $\mathbf{2 . 5 7}$ & Cukup \\
1 & Kemampuan Mengelola Pembelajaran & 2.77 & Cukup \\
2 & Kemampuan Merancang dan Melaksanakan Pembelajaran & 2.52 & Cukup \\
3 & Kemampuan Melaksanakan Evaluasi Pembelajaran & 2.81 & Cukup \\
4 & Kemampuan Pengembangan Peserta Didik & 2.20 & Kurang Baik \\
B & Kompetensi Profesional & $\mathbf{2 . 9 4}$ & Cukup \\
1 & Kemampuan penguasan dan Pemahaman Materi & 3.08 & Cukup \\
2 & Kemampuan Mengelola Proses Pembelajaran dan Kelas & 2.80 & Cukup \\
C & Kompetensi Sosial & $\mathbf{3 . 0 5}$ & Cukup \\
1 & Kemampuan Komunikasi, Bekerjasama, Agama, dan & 3.05 & Cukup \\
& Budaya & & \\
D & Kompetensi Kepribadian & $\mathbf{3 . 0 1}$ & Cukup \\
1 & Keteladanan & 3.02 & Cukup \\
2 & Kedisiplinan & 2.99 & Cukup \\
\hline & $\quad$ Rerata Total & 2.89 & 2.89 \\
\hline
\end{tabular}

Secara visual kompetensi guru bahasa Arab berdasarkan persepsi siswa MAN IC Bangka Tengah digambarkan sebagai berikut:

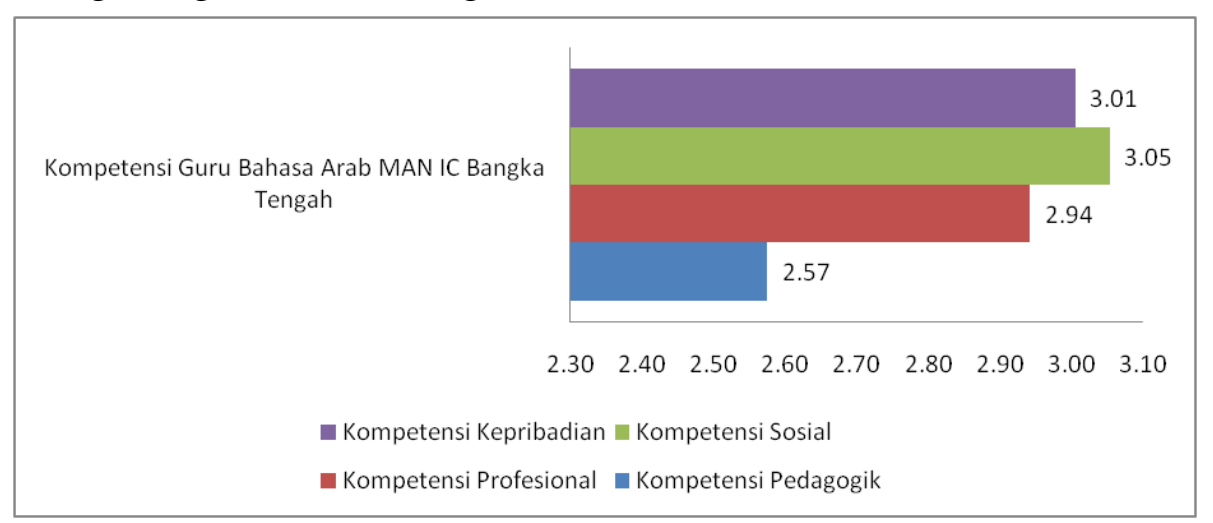

c. Kompetensi Guru Bahasa Arab MAN 1 Bangka

Berdasarkan hasil pengolahan dan analisis data didapat bahwa siswa MAN 1 Bangka mempersepsikan kompetensi guru bahasa Arab sebesar 2.99 masuk pada kategori "Cukup". Adapun jika dilihat berdasarkan kompetensi, diketahui kompetensi pedagogik guru yang terendah dengan skor sebesar 2.72 pada kategori "Cukup". Kemampuan pengembangan peserta didik kiranya perlu mendapat perhatian guru. Dalam hal ini, siswa merasa bahwa guru kurang mampu memberikan upaya 
pengembangan atas kemampuan siswa. Skor pengembangan peserta didik tergolong "Kurang Baik" dengan skor sebesar 2.58. Secara rinci sebaran skor kompetensi guru bahasa Arab berdasarkan persepsi siswa dapat disajikan pada tabel di bawah ini:

Tabel 11. Kompetensi Guru Bahasa Arab Ditinjau Dari Persepsi Siswa MAN 1 Bangka

\begin{tabular}{clcc}
\hline No & \multicolumn{1}{c}{ Kompetensi Guru Bahasa Arab } & Rerata & Keterangan \\
\hline A & Kompetensi Pedagogik & $\mathbf{2 . 7 2}$ & Cukup \\
1 & Kemampuan Mengelola Pembelajaran & 2.82 & Cukup \\
2 & Kemampuan Merancang dan Melaksanakan & 2.59 & Cukup \\
& Pembelajaran & & \\
3 & Kemampuan Melaksanakan Evaluasi Pembelajaran & 2.90 & Cukup \\
4 & Kemampuan Pengembangan Peserta Didik & 2.58 & Cukup \\
& & & \\
B & Kompetensi Profesional & $\mathbf{3 . 0 8}$ & Cukup \\
1 & Kemampuan penguasan dan Pemahaman Materi & 3.19 & Cukup \\
2 & Kemampuan Mengelola Proses Pembelajaran dan Kelas & 2.97 & Cukup \\
& & & \\
C & Kompetensi Sosial & $\mathbf{3 . 0 6}$ & Cukup \\
1 & Kemampuan Komunikasi, Bekerjasama, Agama, dan & 3.06 & Cukup \\
& Budaya & & \\
& & & \multirow{3}{*}{ Cukup } \\
D & Kompetensi Kepribadian & 3.05 & Cukup \\
1 & Keteladanan & 3.17 & Cukup \\
\hline & Kedisiplinan & 2.99 & Cukup \\
\hline
\end{tabular}

Secara visual kompetensi guru bahasa Arab berdasarkan persepsi siswa MAN 1 Bangka digambarkan sebagai berikut:

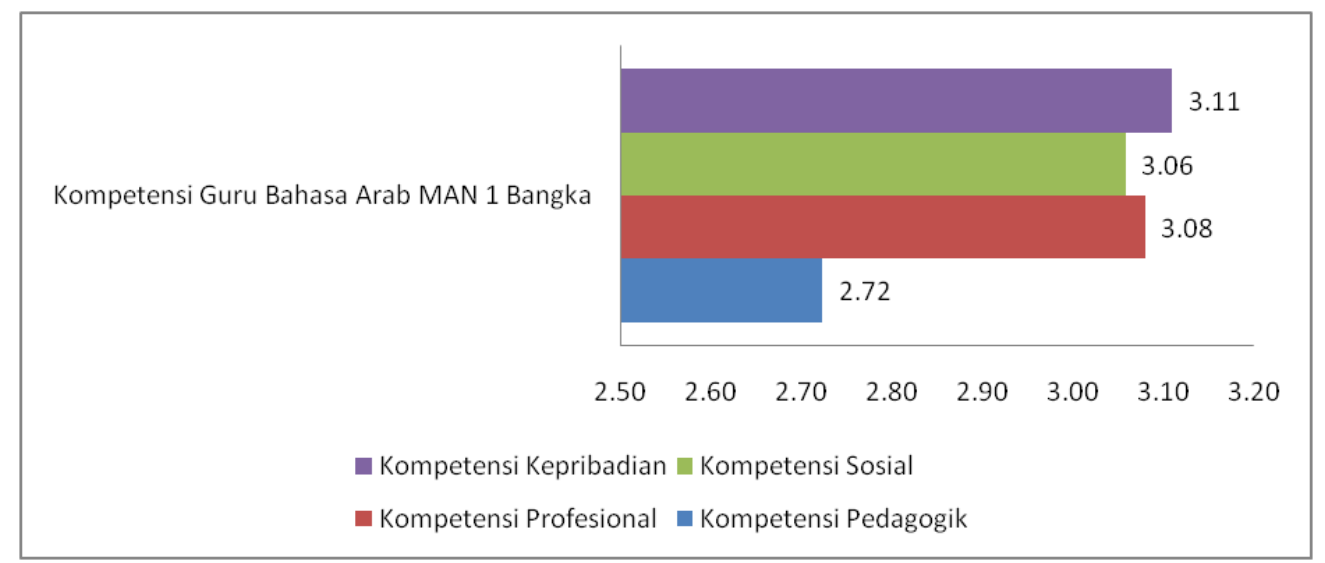


|SYARIFAH | Profil dan Kompetensi Guru Bahasa Arab...

d. Rekapitulasi Kompetensi Guru Bahasa Arab

Jika dilihat berdasarkan asal Madrasah, tidak ada perbedaan yang berarti kompetensi guru antara ketiga Madrasah. Kompetensi guru bahasa Arab tergoling "Cukup" dengan skor penilaian siswa sebesar 2.99. Dari ketiga Madrasah kompetensi pedagogik guru menjadi persoalan utama yang perlu mendapat perhatian guru. Kompetensi pedagogik guru menduduki peranan penting dalam kegiatan pembelajaran di kelas. Secara rinci kompetensi guru bahasa Arab pada ketiga sekolah dapat dilihat pada tabel dan histogram di bawah ini:

Tabel 12. Kompetensi Guru Bahasa Arab Ditinjau Dari Persepsi Siswa MAN di Bangka Belitung

\begin{tabular}{clcc}
\hline No & \multicolumn{1}{c}{ Kompetensi Guru Bahasa Arab } & Rerata & Keterangan \\
\hline A & Kompetensi Pedagogik & $\mathbf{2 . 6 4}$ & Cukup \\
1 & Kemampuan Mengelola Pembelajaran & 2.80 & Cukup \\
2 & Kemampuan Merancang dan Melaksanakan Pembelajaran & 2.55 & Cukup \\
3 & Kemampuan Melaksanakan Evaluasi Pembelajaran & 2.83 & Cukup \\
4 & Kemampuan Pengembangan Peserta Didik & 2.36 & Kurang \\
& & & Baik \\
B & Kompetensi Profesional & $\mathbf{3 . 0 0}$ & Cukup \\
1 & Kemampuan penguasan dan Pemahaman Materi & 3.10 & Cukup \\
2 & Kemampuan Mengelola Proses Pembelajaran dan Kelas & 2.89 & Cukup \\
C & Kompetensi Sosial & $\mathbf{3 . 0 3}$ & Cukup \\
1 & Kemampuan Komunikasi, Bekerjasama, Agama, dan & 3.03 & Cukup \\
& Budaya & & \\
D & Kompetensi Kepribadian & $\mathbf{3 . 0 4}$ & Cukup \\
1 & Keteladanan & 3.02 & Cukup \\
2 & Kedisiplinan & 3.05 & Cukup \\
\hline & $\quad$ Rerata Total & 2.99 & Cukup \\
\hline
\end{tabular}

Secara visual kompetensi guru bahasa Arab berdasarkan persepsi siswa pada tiga Madrasah digambarkan sebagai berikut:

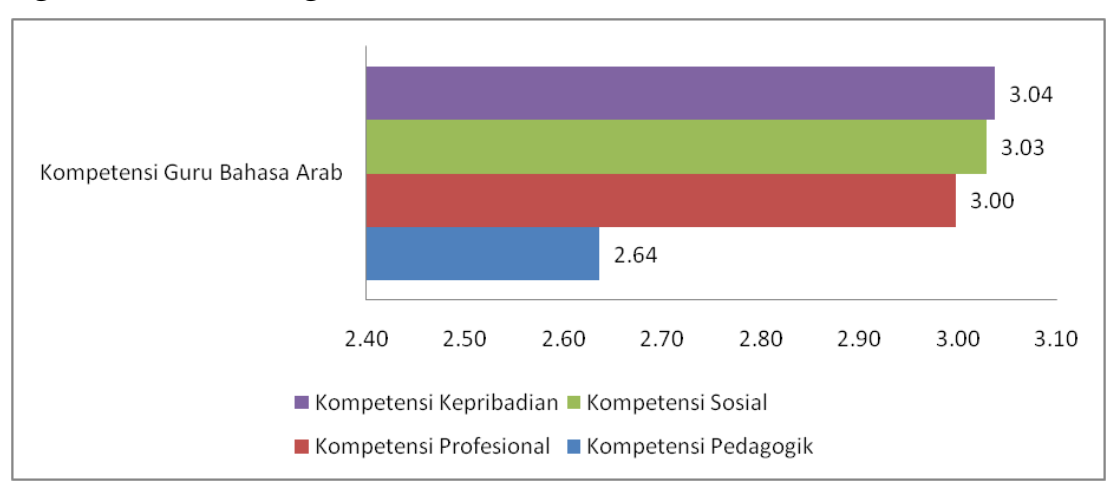




\section{Kesimpulan}

Berdasarkan temuan penelitian dapat disimpulkan bahwa profil guru bahasa Arab berdasarkan kualifikasi akademik, guru bahasa Arab yang sudah memiliki kualifikasi akademik S1 PBA memiliki prosentasi sebesar 80\% dan kualifikasi akademik S1 lainnya sebesar 20\%. Mengacu kepada data tersebut relevansi keilmuan guru bahasa Arab dengan mata pelajaran yang diampu berdasarkan kualifikasi akademik sebesar 80:20. Sedangkan jika relevansi keilmuan ditinjau dari sertifikat pendidik, guru bahasa Arab yang memiliki sertifikat pendidik sebagai guru bahasa Arab profesional sebesar $60 \%$ dan yang belum tersertifikasi sebesar $40 \%$.

Berdasarkan perspektif siswa kompetensi guru bahasa Arab di Madrasah Aliyah Negeri Provinsi Kepulauan Bangka Belitung adalah sebagai berikut: Kompetensi Pedagogik dengan rerata skor sebesar 2.64, Kompetensi Profesional sebesar 3.00, Kompetensi Sosial dengan rerata skor 3.03, dan Kompetensi Kepribadian sebesar 3.04. Rerata skor secara umum dari empat kompetensi tersebut adalah 2.99 dengan interpretasi “Cukup”. Dari ketiga madrasah yang menjadi obyek penelitian, kompetensi pedagogik guru menjadi persoalan utama yang perlu mendapat perhatian guru. 
|SYARIFAH | Profil dan Kompetensi Guru Bahasa Arab...

\section{DAFTAR PUSTAKA}

AININ, M.O.H., 'Pembelajaran Bahasa Arab motivasional', Prosiding Konfererensi Nasional Bahasa Arab, vol. 1, no. 1, 2015.

Amirudin, Noor, 'Problematika Pembelajaran Bahasa Arab', TAMADDUN, 2017, pp. 1-12.

Bahri, Saiful, 'Supervisi akademik dalam peningkatan profesionalisme guru', Visipena Journal, vol. 5, no. 1, 2014, pp. 100-12.

Chuan, Chua Lee and Jabatan Penyelidikan, 'Sample size estimation using Krejcie and Morgan and Cohen statistical power analysis: A comparison', Jurnal Penyelidikan IPBL, vol. 7, no. 1,2006 , pp. $78-86$.

Darimi, Ismail, 'Peningkatan Kompetensi Pedagogik Guru PAI dalam Pembelajaran', Jurnal MUDARRISUNA: Media Kajian Pendidikan Agama Islam, vol. 5, no. 2, 2015, pp. 309-24.

Darmadi, Hamid, 'Tugas, Peran, Kompetensi, dan Tanggung Jawab Menjadi Guru Profesional', Edukasi: Jurnal Pendidikan, vol. 13, no. 2, 2016, pp. 161-74.

Hadari, Nawawi, 'Organisasi Sekolah dan Pengelolaan Kelas Sebagai Lembaga Pendidikan', Jakarta: Gunung Agung, 2002.

Hakim, Lukman, 'Pemerataan Akses Pendidikan Bagi Rakyat Sesuai Dengan Amanat UndangUndang Nomor 20 Tahun 2003 Tentang Sistem Pendidikan Nasional', EduTech: Jurnal Ilmu Pendidikan dan Ilmu Sosial, vol. 2, no. 1, 2016.

Hamid, Abdul, 'Guru Profesional', Al-Falah: Jurnal Ilmiah Keislaman dan Kemasyarakatan, vol. 17 , no. 2, 2017, pp. 274-85.

Handriawan, Dony, 'Mempertegas Kembali Arah Pembelajaran Bahasa Arab: Perspektif Budaya terhadap Tradisi Belajar Bahasa Arab di Indonesia" dalam Al-Mahāra', Jurnal AlMahara, vol. 1, no. 1, 2015, pp. 43-64.

Hasnawati, J., 'Implementasi Kompetensi Profesionalisme Guru dalam Pengembangan Kinerja Pembelajaran', Inspiratif Pendidikan, vol. 5, no. 1, 2016, pp. 77-93.

Hendri, Edi, 'Guru berkualitas: profesional dan cerdas emosi', Jurnal saung guru, vol. 1, no. 2 , 2010, p. 1.

Huraerah, Ahmad Junaedy Abu, 'Etika Guru dalam Perspektif al-Timidzi (Studi Atas Kitab Sunan al-Tirmidzi Karya Abu Isa Muhammad Bin Isa al-Tirmidzi)', Journal of Islamic Education Policy, vol. 1, no. 2, 2017.

Idris, Saifullah and Z.A. Tabrani, 'Realitas Konsep Pendidikan Humanisme dalam Konteks Pendidikan Islam', Jurnal Edukasi: Jurnal Bimbingan Konseling, vol. 3, no. 1, 2017, pp. 96-113.

Indonesia, Pemerintah Republik, Undang Undang Republik Indonesia No. 16 Tahun 2007 tentang Standar Kualifikasi Guru dan Dosen, Jakarta, 2003.

Indonesia, Tim Penyusun Kamus Besar Bahasa, 'Kamus besar bahasa Indonesia', Jakarta: Balai Pustaka, 2008.

Islam, Asep Muhammad Saepul, 'Faktor Demotivasi Pembelajaran Bahasa Arab dalam Perspektif Siswa Madrasah', Arabiyât: Jurnal Pendidikan Bahasa Arab dan Kebahasaaraban, vol. 2, no. 1, 2015, pp. 1-16.

Jatirahayu, Warih, 'Guru Berkualitas Kunci Mutu Pendidikan', Jurnal Ilmiah Guru Caraka Olah Pikir Edukatif, 2013.

Juhji, Juhji, 'Peran Urgen Guru dalam Pendidikan', Studia Didaktika, vol. 10, no. 01, 2016, pp. $51-62$.

Kesumawati, Nila, 'PROFESIONALISME DAN KESEJAHTERAAN GURU', Jurnal Dosen Universitas PGRI Palembang, 2015.

Latiana, Lita, 'Peran Sertifikasi Guru dalam Meningkatkan Profesionalisme Pendidik', Edukasi, vol. 1, no. 1, 2016. 
Makruf, Imam, 'Manajemen Integrasi Pembelajaran Bahasa Arab di Madrasah Berbasis Pondok Pesantren', Cendekia: Jurnal Kependidikan Dan Kemasyarakatan, vol. 14, no. 2, 2016, pp. $265-80$.

Marjuni, A., 'Tanggung Jawab Guru Dalam Pengembangan Kompetensi Profesional', Inspiratif Pendidikan, vol. 5, no. 1, 2016, pp. 116-26.

Matnuh, Harpani, 'Perlindungan Hukum profesionalisme Guru', Jurnal Pendidikan Kewarganegaraan, vol. 7, no. 2, 2017, pp. 46-50.

Muhaimin, M.A. and Nur Ali, 'Paradigma Pendidikan Islam', Bandung, Rosda Karya, 2002.

Mulyasa, Enco, Kurikulum berbasis kompetensi: konsep, karakteristik, dan implementasi, PT Remaja Rosdakarya, 2002.

Muntahibun, Muhammad, 'Ilmu Pendidikan Islam', Yogyakarta: Teras, 2011.

Muradi, Ahmad, 'Tujuan Pembelajaran Bahasa Asing (Arab) Di Indonesia', Jurnal Al Maqayis, vol. 1, no. 1, 2014.

Nadziroh, Nadziroh, Chairiyah Chairiyah, and Wachid Pratomo, 'Hak Warga Negara dalam Memperoleh Pendidikan Dasar di Indonesia', Trihayu, vol. 4, no. 3, Sarjanawiyata Tamansiswa University, 2018.

Naim, Ngainun, Menjadi guru inspiratif: memberdayakan dan mengubah jalan hidup siswa, Pustaka pelajar, 2009.

Ramayulis, Ilmu Pendidikan Islam, Kalam Mulia, Jakarta, 2008.

RI, Kementerian Pendidikan Nasional, Undang-Undang RI No. 14 Tahun 2005 tentang Guru dan Dosen, BP. Cipta jaya, 2019.

Samani, Muchlas and Muchlas Samani, Mengenal sertifikasi guru di Indonesia, Diterbitkan bersama oleh Penerbit SIC dan Asosiasi Peneliti Pendidikan Indonesia, 2006.

Saputra, Hendra Dani, Faisal Ismet, and Andrizal Andrizal, 'Pengaruh Motivasi Terhadap Hasil Belajar Siswa SMK', Invotek: Jurnal Inovasi Vokasional dan Teknologi, vol. 18, no. 1, 2018, pp. 25-30.

Slameto, Belajar Dan Faktor-Faktor Yang, 'Mempengaruhinya', Jakarta: Rineka cipta, 2003.

Suardi, M., 'PENGARUH KEPRIBADIAN GURU PAI TERHADAP HASIL BELAJAR SISWA DI SEKOLAH', IQRO: Journal of Islamic Education, vol. 1, no. 2, 2018, pp. $121-8$

Sudiyono, Muhammad, 'Ilmu Pendidikan Islam', Jakarta: Rineka Cipta, 2009.

Susanto, Ahmad, Pemikiran Pendidikan Islam, Amzah, 2009.

Sutarman, Sutarman, 'GURU DAN PESERTA DIDIK DALAM PERSPEKTIF PENDIDIKAN ISLAM', AL-MISBAH (Jurnal Islamic Studies), vol. 5, no. 1, 2019, pp. 34-50.

Undang-Undang, R.I., 'No. 20 Tahun 2003 Tentang Sistem Pendidikan Nasional. 2003', Jakarta: Sinar Grafika, 2013.

Vito, Benediktus and Hetty Krisnani, 'Kesenjangan pendidikan desa dan kota', Prosiding Penelitian dan Pengabdian kepada Masyarakat, vol. 2, no. 2, 2015.

Waton, Muhammad Nasrul, 'Sertifikasi Guru menuju Profesionalisme Pendidik', Tafáqquh: Jurnal Penelitian Dan Kajian Keislaman, vol. 4, no. 1, 2016, pp. 1-11.

Wina, Sanjaya, 'Pembelajaran dalam Implementasi Kurikulum Berbasis Kompetensi', Jakarta: Kencana Prenada Media Group, 2005.

Yanizon, Ahmad and Nellida Purba, 'HUBUNGAN ANTARA SIKAP ORANG TUA DENGAN MINAT BELAJAR SISWA', KOPASTA: Jurnal Program Studi Bimbingan Konseling, vol. 4, no. 1, 2017. 